\title{
DEPARTMENT of APPLIED SCIENCE
}

Polymer-Concrete Composites

for

Energy Related Systems

Progress Report No. 3

October-December 1974

Radiation Division

B. Manowitz, Head.

M. Steinberg, Assóciațe Head

L. E. Kukacka, Project Leader

Contributors:

L . E. Kukacka

A. Auskern

J. Fontana

This report was prepared as an account of work sponsored by the United States Government. Neither the United States nor the United States Energy Research and Development Administration, nor any of Research and Development Administration, their employees, nor any of their contractors, any subcontractors, or their employees, makes legal warranty, express or implied, or assumes any legal liability or responsibility for the accuracy, completeness or usefulness of any information, apparatus, product or or usefulness of any infores process disclosed, or represents

\section{BROOKHAVEN NATIONAL LABORATORY UPTON, NEW YORK II973}




\section{DISCLAIMER}

This report was prepared as an account of work sponsored by an agency of the United States Government. Neither the United States Government nor any agency Thereof, nor any of their employees, makes any warranty, express or implied, or assumes any legal liability or responsibility for the accuracy, completeness, or usefulness of any information, apparatus, product, or process disclosed, or represents that its use would not infringe privately owned rights. Reference herein to any specific commercial product, process, or service by trade name, trademark, manufacturer, or otherwise does not necessarily constitute or imply its endorsement, recommendation, or favoring by the United States Government or any agency thereof. The views and opinions of authors expressed herein do not necessarily state or reflect those of the United States Government or any agency thereof. 


\section{DISCLAIMER}

Portions of this document may be illegible in electronic image products. Images are produced from the best available original document. 
Brookhaven National Laboratory Department of Applied Science Upton, New York 11973

Polymer-Concrete Composites

for

Energy Related Systems

Progress Report No. 3

October-December 1974

Radiation Division

B. Manowitz, Head

M. Steinberg, Associate Head

I. E. Kukacka, Project Leader

Contributors:

I. E. Kukacka

A. Auskern

J. Fontana 


\section{Polymer-Concrete Composites \\ for \\ Energy Related Systems \\ Progress Report No. 3 \\ October-December 1974}

\section{Introduction}

Concrete-polymer materials have been under development at BNL for several years. The work has progressed to the point that the feasibility for several energy related applications has become apparent. These include the following:

(1) polymer-concrete (PC) linings for pipe and vessels used in geothermal power systems, (2) PC as a material to cement well casings in oil and geothermal wells, (3) the incorporation of waste products into PC which can be used as construction materials, (4) the use of polymer-impregnated concrete (PIC) for pilings, pipe, railroad ties, Arctic structures subject to ice abrasion, and devices to prevent the formation of ice on canal lock walls. The feasibility of using PC for prestressed concrete reactor vessels for the HTGR may also be investigated. Development work has been started on applications 1-4. Field testing of PIC as a material of construction for use in systems to prevent the build-up of ice on canal 
lock walls was started. Field testing of PC in geothermal systems will be started during the next report period.

II. PC Materials Testing

The experiment in which various PC materials were exposed in an autoclave to a synthetic geothermal brine at a temperature of $177^{\circ} \mathrm{C}$ was concluded after a 100 day exposure. This test was described in the previous progress report. Because of the limitation in the number of specimens available, only two PC compositions, 60 wt \% styrene - 40 wt \% TMPTMA and 50 wt \% styrene - 33 wt \% acrylonitrile (ACN) - 17 wt \% TMPTMA were exposed for the full duration of the test. The other two systems were removed from the test after 35 days. Compared to the compressive strength after 14 days exposure, all materials exhibited little loss in strength. It appears that there may be some inconsistencies in the initial test results, which can probably be attributed to poor surface preparation of the samples prior to strength testing.

The strengths of the styrene-ACN-TMPTMA PC were of the order of 9-10,000 psi after the brine exposure. The initial strength was about 8,000 psi. For the styrene-TMPTMA PC samples, the initial strength was $6,400 \mathrm{psi}$ and decreased to 3,500 psi. However, most of the strength decrease appeared to take place during the first two weeks. It should be 
noted that these strengths were measured at roo'm temperature and probably do not represent strengths at $177^{\circ} \mathrm{C}$. The test data are summarized in Figure 1.

The PC specimens before and after the 100 day exposure are shown in Figure 2. The upper pair contain styrene-ACNTMPTMA; the bottom pair contain styrene-TMPTMA polymer. All of these samples have been tested in compression. The exposed samples have retained their shape and sharp edges but have darkened on the surface, probably due to the discoloration of the brine solution.

In conjunction with the strength testing, thermogravimetric and differential thermal analysis (DTA) measurements have been made on polymer samples extracted from the specimens. These tests are performed in order to obtain another indication of the stability of the polymers after exposure to the high temperature brine environment. In some polymers considerable changes to the thermograms have occurred. For example, for $60 \%$ styrene $-40 \%$ acrylonitrile, the endothermic peak at $430^{\circ} \mathrm{C}$ in the control sample is no longer present and an exothermic peak has appeared at $370^{\circ} \mathrm{C}$ after 5 weeks in test. Also, the temperature at which maximum weight loss occurs has decreased from $425^{\circ} \mathrm{C}$ in the control sample to $380^{\circ} \mathrm{C}$ after 5 weeks exposure. In spite of these changes, which 
COMPRESSIVE STRENGTH AFTER

EXPOSURE TO SIMULATED

GEOTHERMAL BRINE AT $177^{\circ} \mathrm{C}$

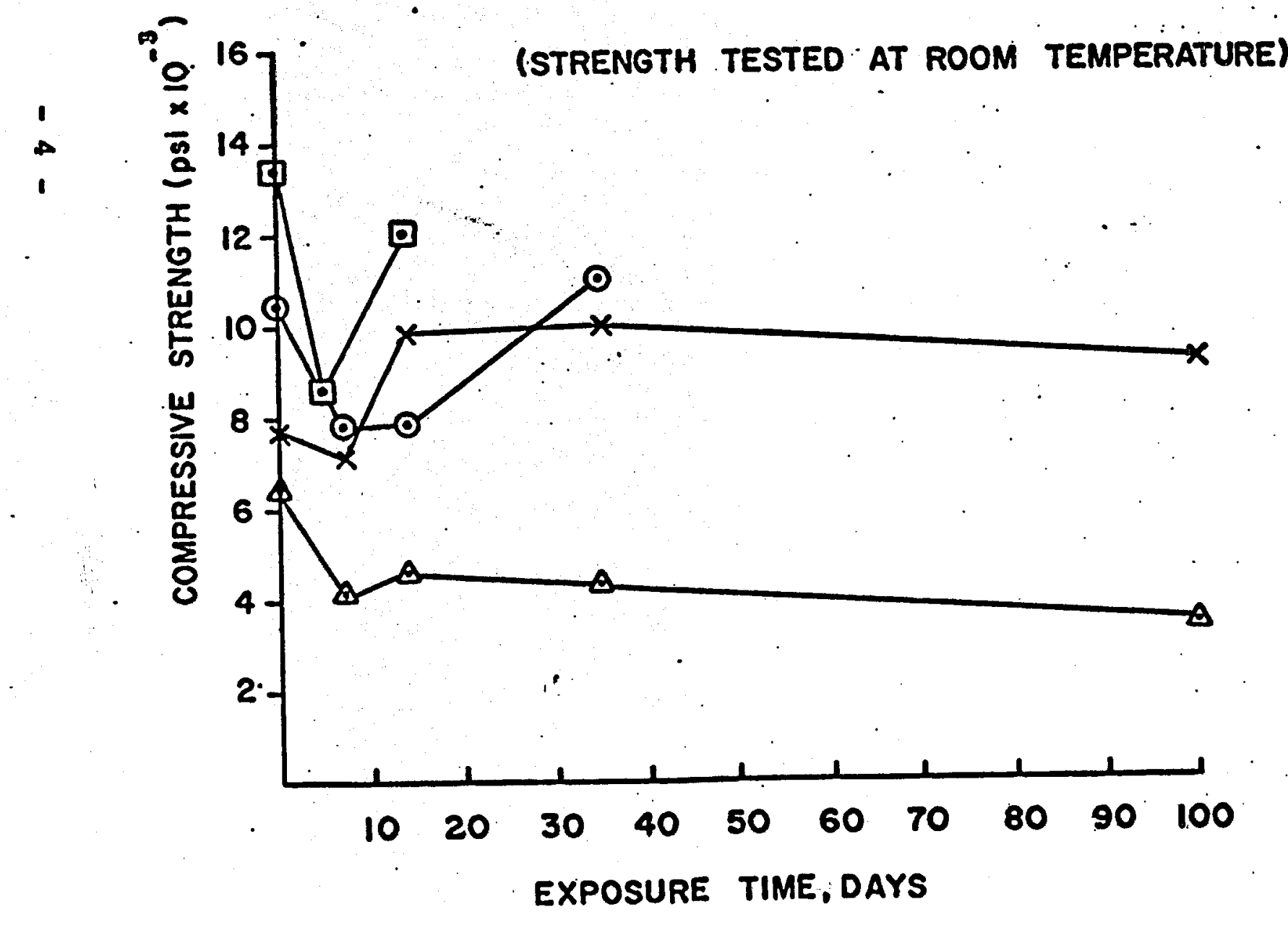

$O(60-40)$ STYRENE-ACN

$\square(60-40)$ STYRENE-ACN

(FLAMED)

$\Delta(60-40)$ STYRENE-TMPTMA

$\times(50-33-17)$ STYRENE-ACNTMPTMA 

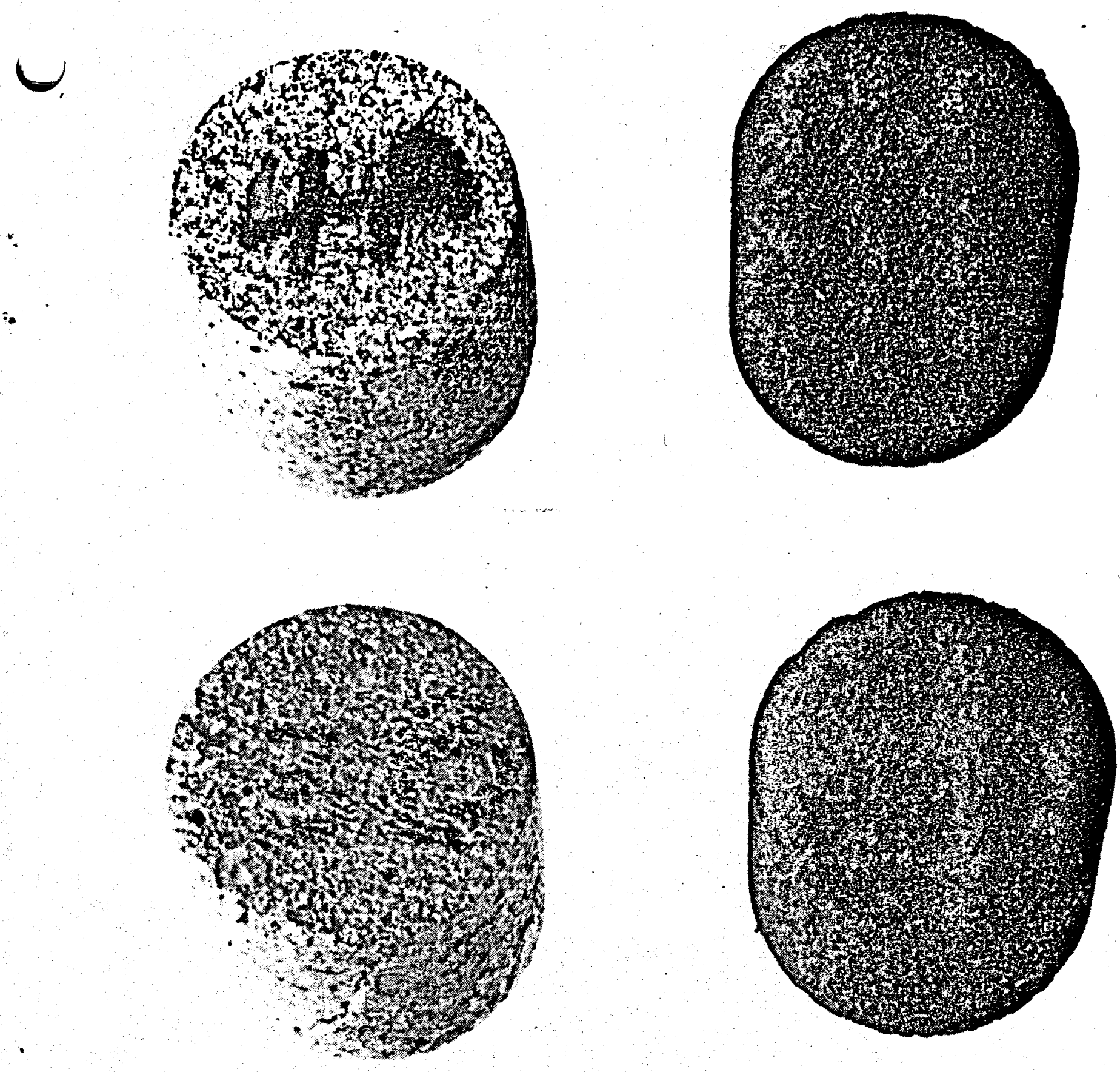

Figure 2

Polymer concrete test specimens. Upper pair (marked 4) contain styreneACN-TMPTMA. Lower pair (marked 3) contain styrene-TMPTMA. The samples on the left are controls that were tested in compression. Samples on the right were exposed to the brine solution for 100 days at $177^{\circ} \mathrm{C}$. 
indicate the formation of a less thermally stable material, the strengths at room temperature have not been appreciably affected. These thermal analysis results are summarized in Table 1. Note that the styrene-TMPTMA polymer, after 100 days exposure, appears to be more stable than the control samples.

The 100 day test specimens were also evaluated for dimensional change and weight change. The diameters of the styrene-TMPTMA and styrene-ACN-TMPTMA PC specimens increased $0.3 \%$ and the weight increases were about $4.5 \%$ and $7 \%$ respectively. These changes are shown in Figure 3.

Continued high temperature testing is underway in a PC lined pressure vessel. A lining of $60 \%$ styrene $-40 \%$ TMPTMA PC was applied to the sandblasted surface of a 6-in. diam $\times 15-i n$. long pressure vessel. The polymer was cured using promoter-catalyst systems and curreatly contains a simulated geothermal brine at about $218^{\circ} \mathrm{C}$. This is the highest temperature to which this PC formulation has been exposed. The condition of the lining will be periodically monitored. A photograph of the lined pressure vessel, prior to start-up is shown in Figure 4.

Twenty-eight specimens of the styrene-TMPTMA PC and an equal number-containing styrene-ACN-TMPTMA have been. 
Table 1

Summary of Thermal Analysis Testing of PC Exposed to Synthetic Geothermal Brines at $177^{\circ} \mathrm{C}$

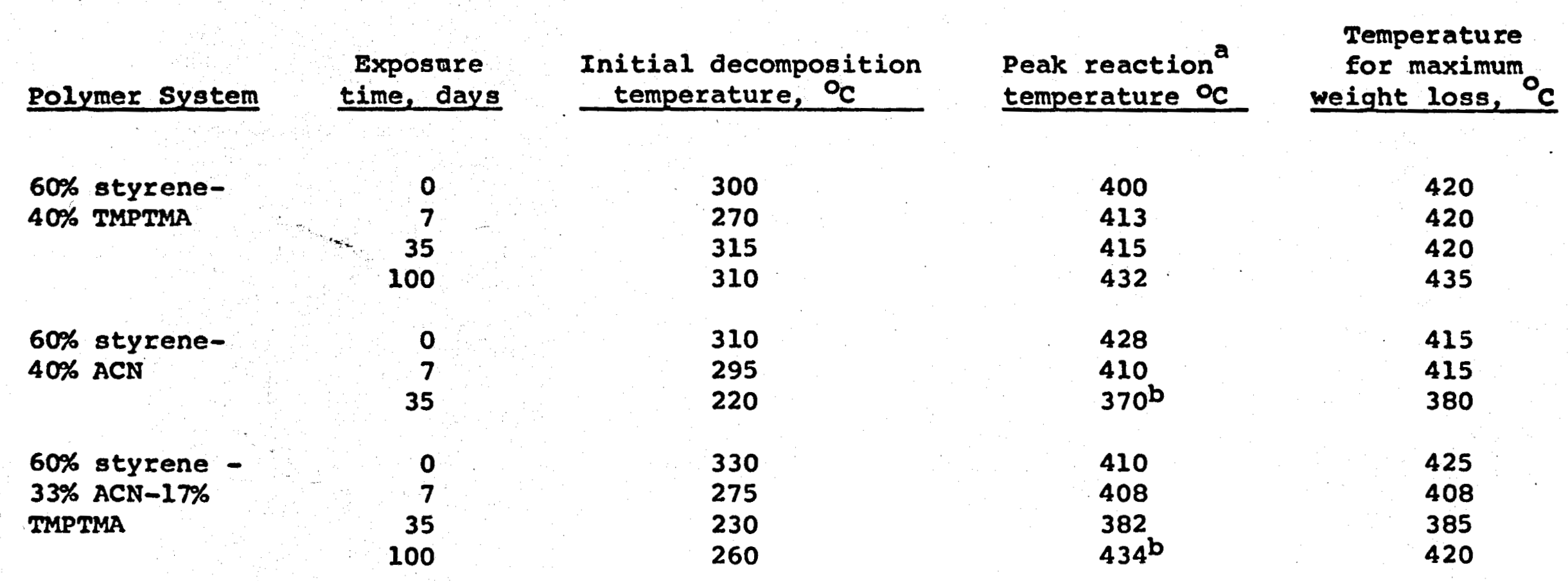

a, endothermic peak unless noted

b, exothermic peak 


fabricated for use in autoclave tests at $218^{\circ} \mathrm{C}$, compressive strength tests, and measurements of the thermal coefficient of expansion. These tests will commence during the next report period.

Tests to determine the effect of thermal shock on PC Iined steel pipe have been started. In the initial test, a 0.5-in. thick PC liner containing 60\% styrene-40\% TMPTMA was placed on the inside of an 8-in.-diam steel pipe. The surface of the pipe was sandblasted prior to application of the PC. The specimen was cooled to $0^{\circ} \mathrm{C}$ and then immersed in boiling water. After 3 cycles, no cracking or loss of bond is apparent. More severe conditions will be applied in future tests. Plans to initiate field testing of PC materials in geothermal systems have been formulated with the Union oil Company. Three locations; The Geysers, Imperial Valley, and a site in New Mexico, will be utilized.

Several different tests will be performed at The Geysers. In a test to determine the feasibility of using PC as a material for cementing well casings into the hole, fortyeight 2 -in. cubes will be exposed in a well to dry steam at a temperature of $238^{\circ} \mathrm{C}$. Two monomer systems, $60 \%$ styrene40\% TMPTMA and $50 \%$ styrene-33\% ACN- $27 \%$ TMPTMA will be evaluated. Observations will be made after exposure for 
1 and 4 weeks. Weight changes, dimensional changes, and compressive strengths will be determined. These tests should be started during the next report period.

PC lined pipe will also be tested at The Geysers. Test locations will be in a reinjection line where the temperature is $<38^{\circ} \mathrm{C}$ and in an off-gas incinerator line from an $\mathrm{K}_{2} \mathrm{~S}$ scrubber. In the latter, the PC will be exposed to a sulfurous acid solution of $\mathrm{pH} 2$ to 3 at a temperature of $<150^{\circ} \mathrm{C}$. The use of PC as a structural material for the cooling tower support structure will also be evaluated. In this test PC beams, 6x6×24-in., will be placed under the cooling towers for exposure to water. These tests should commence before the end of FY 1975.

PC lined pipe will also be field tested at the Bacca Wells in New Mexico and in the Imperial Valley of California. In these tests the PC will be exposed to $\sim 2$ and $10 \%$ brine solutions respectively. The operating temperature will be $\sim 230^{\circ} \mathrm{C}$. PC cementing materials will also be evaluated at the New Mexico test site.

III. Solid Waste Utilization

The techniques for utilizing solid waste as aggregates in PC are being developed. As the initial part of this effort, waste glass of the type obtained by a "head-end" separation process is being investigated. 
Emphasis is being placed on converting the waste glass into a glass polymer composite (GPC) sewer pipe which could compete with arbestos cement or vitreous clay as a corrosion resistant material. In this manner, waste available from a municipality can be converted into a useful product which can then be utilizẹ by the same municipality.

In an effort to transfer the technology developed in the waste utilization program to the private sector, liason has been established with industrial, municipal, and state groups. The results from this National science Foundation sponsored study were published in a report entitled: Promoting the Utilization of Solid Waste Glass-Polymer Composite Technology in the Public and Private Sector (BNL 19394).

One of the linkages of substance formed during the above study (BNL, Maryland Environmental Services, and Teledyne National) has continued to function during the report period. As part of this effort, personnel from Teledyne are participating in the experimental program at BNL. Studies to optimize the process requirements are being continued. Emphasis is being placed on the selection of mold release agents required for the removal of the GPC pipe from the fabrication form. Monomer composition and concentration are being investigated since they appear to have a strong affect on the mold 
release characteristics. Teledyne is also continuing to conduct market surveys and economic studies.

Iv. Polymer-Impregnated Concrete

The development of the use of polymer-impregnated concrete

(PIC) for use in energy related systems was continuad.

A potential application for PIC is in devices to prevent the formation of ice on canal lock walls. One method is to cast conductive concrete panels for installation on present lock walls, and using electrical energy for heating. The use of PIC would result in an impervious material with a hard, abrasion resistant surface.

In conjunction with the U. S. Army Cold Regions Research and Engineering Laboratory, a series of laboratory tests were performed and a field test is in progress. The laboratory test consisted of the methyl methacrylate-impregnation of fourteen $8 \times 10 \times 3-i n$. concrete-graphite concrete sandwich composites. After impregnation, water absorption and electrical resistivity measurements were made. Based upon the favorable results from these tests, two $4 \times 6-f t \times 3-i n$. panels were impregnated for use in field tests being performed at the Poe Lock which is part of the soo Canal near sault ste. Marie, Michigan. one panel consisted of a 1 -in. thick graph e-concrete core covered with 1-in. layers of steel 
fiber reinforced concrete. The second panel had conventional steel bar reinforcing in place of the steel fiber. The impregnation work was completed in late November and the panels were installed in the lock in December. The in-place panels are shown in Figure 5 . Unimpregnated control panels were also installed. Evaluation tests are currently in progress.

The use of PIC railroad ties in transportation systems is also being investigated. One of the principal problems associated with the use of pretensioned concrete ties is the development of adequate anchorage of the strand. This is overcome by making the ties longer and a special deformed strand is required. Due to the increased bond characteristics, the use of PIC should permit a reduction in tie length and the use of standard strand. Other benefits to be accrued include improved abrasion resistance, bonding strength, bond to rail anchor bolts, and durability.

Preliminary experiments have been initiated. Two 8.5-ft $\times 8 \times 3.5-$ in. prestressed concrete ties and 2 control cylinders supplied by the Blakeslee company have been impregnated. Testing is in progress.

Technical discussions have been held with the Portland Cement Association (PCA) which presently is conducting a 

large program for the Federal Railroad Agency to evaluate concrete ties. As a result, the PCA has requested funding for a cooperative program with BNL to extend the work to PIC ties. 


\section{Distribution}

Energy Research and Development Administration Department of Applied Technology

Edward H. Fleming

Louis B. Werner

Rufus W. Shivers

Morris Skalka

Paul R. Wieber

Joseph J. Perona

Brookhaven National Laboratory

Warren E. Winsche

Bernard Manowitz

Meyer steinberg

Lawrence Kukacka

Allan Auskern

Peter Colómbo

Jack Fontana

John Jewett (ERDA) 